\title{
Role of Land Rent and Capital to Income Households in Indonesia
}

\author{
Endang Taufiqurahman
}

Faculty of Economics and Business, Universitas Padjadjaran, Bandung, Indonesia

Jl. Dipati Ukur Nomor 35 Bandung, 40132, Phone +62-2-2503271 ext 146-156

E-mail address: endangtaufiq@yahoo.co.id

\begin{abstract}
The purpose of the study to determine the effect of land rents and capital on incomes and wages in Indonesian households. Then determine whether the use of the dimensions of wages, as well as the dimensions of income in measuring the influence of capital and land rent-toincome households in Indonesia. This study uses the FD method (First Difference). The data used is panel data sourced from IFLS (Indonesian Family Life Survey) which IFLS-3 in the year 2000, and IFLS-4 in the year 2007. Research results show that an increase in the rent of agricultural land causes decreased significantly to income or household wage in Indonesia. The increase in capital causes a significant slowdown in total household income and wages Indonesia.
\end{abstract}

Keywords: land rent, capital, household income, wage

JEL Classification Codes: D1, J3, R2

\section{Sewa Lahan dan Kapital terhadap Pendapatan Rumah Tangga di Indonesia}

\begin{abstract}
Abstrak
Tujuan penelitian untuk mengetahui pengaruh sewa lahan dan modal kapital terhadap pendapatan dan upah rumah tangga di Indonesia. Kemudian untuk mengetahui apakah pengunaan ukuran upah sama baiknya dengan ukuran pendapatan dalam mengukur pengaruh modal kapital dan sewa lahan terhadap pendapatan rumah tangga di Indonesia. Kajian ini menggunakan metoda FD (First Difference). Data yang dipergunakan adalah data panel yang bersumber dari IFLS (Indonesian Family Life Survey) yaitu IFLS-3 tahun 2000 dan IFLS-4 tahun 2007. Hasil penelitian menunjukkan bahwa peningkatan sewa lahan pertanian menyebabkan penurunan secara signifikan terhadap pendapatan maupun upah rumah tangga di Indonesia. Peningkatan modal kapital menyebabkan penurunan secara signifikan terhadap total pendapatan dan upah rumah tangga Indonesia.
\end{abstract}

Kata kunci: sewa lahan, kapital, pendapatan rumah tangga, upah

Kode Klasifikasi JEL: D1, J3, R2 


\section{Pendahuluan}

Kemiskinan merupakan masalah umum yang dihadapi negara-negara berkembang. Persentase penduduk miskin di Indonesia periode 1996- 2007 berada sekitar 15-24 persen. Jumlah penduduk miskin absolut dengan ukuran konsumsi makanan minimal perkapita perbulan di Indonesia pada periode yang sama berada sekitar 35-50 juta penduduk (Bappenas, 2009). Sementara itu angka kemiskinan di Indonesia menurut publikasi BPS (Biro Pusat Statistik) pada periode 2004- 2011, persentasi penduduk miskin berada sekitar 12,26-17,75 persen, kemudian jumlah menduduk miskin selama periode tersebut sekitar 29,89-39,30 juta penduduk (Biro Pusat Statistik, 2012). Artinya bahwa tingkat kemiskinan di Indonesia selama 1996-2011 menurut ukuran jumlah maupun persentasenya mengalami penurunan, akan tetapi penurunan tersebut belum terlalu menggembirakan. Relatif kecilnya jumlah dan persentase penduduk miskin di Indonesia tersebut juga dikarenakan asumsi garis kemiskinan yang dipergunakan adalah jumlah konsumsi minimal makanan perbulan (jumlah pemenuhan karbohidrat perbulan), andaikata memasukkan komponen kebutuhan hidup lainnya angka kemiskinan tersebut kemungkinan akan meningkat.

Tujuan utama dari penelitian ini adalah untuk mengetahui pengaruh dari modal kapitan dan sewa lahan terhadap pendapatan dan upah rumah tangga. Penelitian ini akan menggunakan data panel tingkat (level) rumah tangga (mikro). Model yang akan dipergunakan adalah model yang dikembangkan oleh Meng Xin dan Harry Wu (1994) yang dimodifikasi oleh penulis. Modifikasi yang dilakukan adalah dengan dengan menghilangkan dan menambahkan beberapa variabel yang ada di dalamnya, kemudian model asal menggunakan metode OLS (Ordinary Least Square) sedangkan metoda analisis yang akan dipergunakan dalam penelitian ini adalah metoda FD (First Difference).

Studi Literatur. Beberapa penelitian mengenai pentingnya peran modal kapital terhadap pendapatan rumah tangga adalah: Bahwa mikro kredit berpengaruh positif terhadap pendapatan rumah tangga (Sayma Rahman dkk, 2009); Modal kapital, dan luas lahan berpengaruh positif terhadap pendapatan rumah tangga (Meng Xin dan Wu Harry, 1994); Kepemilikan aset-aset awal (endowment) berpengaruh positif terhadap pendapatan rumah tangga (Aghion dkk, 1999) (Townsend dan Kaboski, 2005), (Glewwe dan Grosh, 1998) (Hall dkk, 1999).

Beberapa metode penelitian yang pernah diterapkan untuk meneliti tentang determinan (faktor-faktor yang mempengaruhi) pendapatan rumah tangga relatif beragam. Misalnya Townsend dan Kaboski (2005) menggunakan studi kasus di negara Thailand, mengukur pengaruh keberadaan kredit mikro terhadap pendapatan di tingkat pedesaan. Penelitian diarahkan pada dua pokok permasalahan yaitu tentang tipe kelembagaan dan peran keanggotaan dalam kredit mikro. Untuk menganalisis peran tipe kelembagaan tersebut, penelitian ini menggunakan metoda TSLS (Two-stage least squares) dan Simultaneous Equation MLE (maximum likelihood estimator).

Fafchamps dan Quisumbing (1999) menggunakan data panel negara Pakistan. Model penelitian yang digunakan adalah model maksimasi nilai guna (Utility maximization). Penelitian ini dilakukan untuk melihat pengaruh jumlah tenaga kerja, vektor input variabel, peralatan dan input semi tetap (semi-fixed input), dan vektor karakteristik dari modal manusia terhadap pendapatan rumah tangganya. Penelitian ini menggunakan metoda IV (Instrumental Variabel) untuk melakukan instrumentasi menggunakan BMI (Body Mass Index) untuk mengukur modal manusia.

Meng Xin dan Harry Wu (1994) menggunakan data pada perekonomian China dengan model dasar berdasarkan New Growth Theory, dengan penekanan pentingnya peran sumber daya manusia. Pendapatan dicerminkan berupa jumlah produksi pada suatu rumah tangga, ditentukan oleh variabel-variabel yang terdiri dari: input tenaga kerja, stok modal, tanah yang disewa oleh rumah tangga, jumlah tahun sekolah, dan jumlah tahun pengalaman kerja dari tenaga kerja, ukuran keluarga, jumlah hari kerja, jumlah hari kerja di sektor pertanian, dan pengaruh dummy wilayah. Penelitian ini 
menggunakan metoda estimasi OLS (Ordinary Least Square).

Metode Analisis. Penelitian yang akan dilakukan akan menggunakan metoda FD (First Difference) yang merupakan turunan (bagian) dari metoda DID (Difference in Difference). Metoda FD adalah salah satu metoda yang sering digunakan dalam melakukan evaluasi kebijakan (impact evaluation) (Khandker, 2010). Peran dari metoda FD adalah dengan membuat asumsi bahwa faktor-faktor heterogenitas yang tidak terobservasi (unobserved heterogeneity) adalah ada atau terjadi akan tetapi faktor-faktor tersebut dianggap tidak berubah sejalan perkembangan waktu (time invariant).

Bahwa prinsip dasar dari metoda analisis FD adalah mengukur perubahan dari periode awal ke periode akhir. Secara matematis bisa dikatakan proses tersebut dengan melakukan diferensiasi dari periode akhir ke periode awal atau dari suatu tittik ke titik sebelumnya. Dalam bahasa sederhana bisa dianalogikan proses FD tersebut adalah suatu cara untuk mencari selisih antara dua situasi atau variabel antar waktu. Penggunaan metoda FD dalam penelitian ini tidak bermaksud menguji pelaksanaan suatu kebijakan (pemerintah maupun swasta), tetapi penelitian ini bertujuan membuktikan bahwa metoda FD bisa melakukan proses analisis yang sedikit berbeda dengan metoda lain tapi mampu menghasilkan output yang sama baiknya dengan metoda yang lain.

Penelitian ini meskipun bukan untuk melihat evaluasi dari suatu penerapan kebijakan, akan tetapi penerapan metoda FD sebagai bagian dari metoda DID (Difference in Difference) dapat diterapkan untuk melihat bagaimanan perubahan yang terjadi dari periode awal terhadap periode akhir (Khandker, 2010). Adapun proses estimasi menggunakan FD dapat dirinci sebagai berikut:

Model:

$Y_{i}=\beta_{0}+\delta_{0} d 2_{t}+\beta_{1} X_{i t}+a_{i}+\mu_{i t}$

dimana $Y$ adalah variabel tidak bebas (dependen) dan $X$ adalah variabel bebas (indipenden), serta $d 2$ adalah dummy waktu, kemudian $v_{i t}=a_{i}+\mu_{i t}$ adalah composite error term, dan $a_{i}$ adalah unobserved fixed effect (unobserved heterogeneity), dimana $a_{i}$ adalah tetap antar waktu dan spesifik untuk setiap individu (specific to each individual). $\mu_{i t}$ adalah idiosyncratic error yaitu bervariasi antar individu dan antar waktu. Proses diferensiasi untuk menghilangkan unobserved heterogeneity $\left(a_{i}\right)$ pada pengujian dua periode :

Periode 2:

$Y_{i 2}=\left(\beta_{0}+\delta_{0}\right)+\beta_{1} X_{i 2}+a_{i}+\mu_{i 2}$

Periode 1:

$Y_{i 1}=\beta_{0}+\beta_{1} X_{i 1}+a_{i}+\mu_{i 1}$

First Differencing :

$Y_{i 2}-Y_{i 1}=\delta_{0}+\beta_{1}\left(X_{i 2}-X_{i 1}\right)+\mu_{i 2}-\mu_{i 1}$

$\Delta Y_{i 2}=\delta_{0}+\beta_{1} \Delta X_{i 2}+\Delta \mu_{i 2}$

Adapun bentuk penulisan lengkap dari First Differencing di atas untuk kejelasan penafsiran adalah :

$\Delta Y_{i 2}=\delta_{0} d 2_{2}+\beta_{1} \Delta X_{i 2}+\Delta \mu_{i 2}$

Selanjutnya untuk menyesuaikan dengan lambang dan simbol yang di tuliskan pada bentuk ekonometika standar, maka persamaan tersebut menjadi:

$\Delta Y_{i 2}=\alpha+\beta t_{2}+\gamma \Delta T_{i 2}+\Delta \varepsilon_{i 2}$

Variabel $t_{2}$ adalah dummy periode kedua, $T_{i 2}$ adalah variabel Treatment. Adapun model ekonometrika dasar FD yang akan dipergunakan adalah sebagaimana diungkapkan oleh Howard (1999):

$Y_{i t}=\alpha+\beta t+\gamma T_{i t}+\varepsilon_{i t}$

Artinya bahwa perubahan yang terjadi pada periode akhir terhadap periode awal akan ditangkap oleh koefisien $(\gamma)$ yang ada didepan varibel $(T)$. Hal tersebut berdasarkan rujukan literatur mengenai metodologi evalusi kebijakan dengan menggunakan metoda FD. Bahwa apabila kelompok data yang dikenakan kebijakan (treatment) dan kelompok data pembanding (control) berasal dari populasi yang sama, kemudian tidak terdapat tahun awal (baseline) maka penggunaan FD adalah dibenarkan (valid) (Howard, 1999).

Terdapat beberapa kelemahan yang harus diakui dan kelebihan dari penggunaan metoda FD sebagai bagian dari rumpun metoda DID 
dibandingkan metoda yang lain. Kelebihan metoda FD adalah: a) Terbebas dari asumsi syarat exogenitas (relaxes the assumption of conditional exogeneity) atau pemilihan (selection) hanya terhadap yang ter-observasi (observed) saja, b) Memungkinkan pelacakan (provides a tractable), sebagai cara intuitif untuk mengukur ketepatan dalam pemilihan data yang tidak terobservasi (unobserved). Sedangkan kelemahan dari metoda DID adalah bersumber dari keyakinan terwujudnya variabel yang tidak berubah antar waktu (time invariant), padahal ada kemungkinan (walaupun kecil) dalam variabel dan kasus tertentu sering tidak realistis.

Masalah lainnya adalah pada pemilihan dan pemilahan sampel, hal ini sebenarnya terjadi pada hampir semua metoda evaluasi kebijakan (impact evaluation). Bahwa proses pengukuran hasil suatu kebijakan membutuhkan dua kelompok sampel data, yaitu kelompok sampel data yang dikenakan kebijakan (target) dan kelompok sampel data yang digunakan sebagai pembanding (kontrol). Terdapat dua masalah utama dalam upaya melakukan evaluasi kebijakan terkait dengan hal tersebut, yaitu: a) Program biasanya diarahkan pada target tertentu (program are targeted), b) Partisipasi individu biasanya sekarela (individual partisipation ussualy voluntary). Ketika program diarahkan kepada target tertentu, misalnya kriteria target ditetapkan oleh pemerintah, maka penetapan tersebut akan menghilangkan sifat acak (randomized) dari sampel data yang akan diambil. Berikutnya bila partisipasi individu adalah sukarela, maka tidak ada jaminan dia akan melakukan sesuatu sebagaimana keharusan dalam penerapan kebijakan tersebut. Sehingga kedua masalah tersebut akan menimbulkan bias dalam hasil pengukuran akibat salah pilih (selection bias). Masalah tersebut muncul sebagai akibat dari kesalahan dalam melakukan pemilahan yang benar dari karakteristik kelompok sampel target yang di kenakan kebijakan (target) dan kelompok sampel pembanding (control). Semua masalah dan proses tersebut secara teori ada dalam proses pengumpulan data tetapi sudah di selesaikan oleh penerbit data IFLS, sehingga data yang di publikasikan oleh IFLS sudah terbebas dari semua masalah tersebut.
Masalah lainnya dalam pengukuran hasil suatu penerapan kebijakan dengan melakukan pemodelan adalah masalah endogenitas (endogeneity). Masalah tersebut terjadi ketika terdapat variabel yang mempengaruhi variabel dependen $(Y)$, ternyata tidak bisa ditangkap pada variabel indipendennya $(X)$, akhirnya akan ditangkap pada variable error-nya $(\varepsilon)$. Sehingga model yang dibuat tersebut tidak bisa menjelaskan dengan lengkap dan kuat terhadap kondisi yang sesungguhnya.

Aplikasi Metoda FD pada pengukuran pengaruh Modal kapital dan Sewa lahan. Model yang akan dipergunakan dalam penelitian ini adalah model yang dikembangkan oleh Meng Xin dan Harry Wu (1994) yang dimodifikasi oleh penulis. Proses modifikasi dilakukan melalui tahapan sebagai berikut: 1) Model Meng Xin dan Harry Wu dijadikan kerangka dasar dalam keberhasilannya menjelaskan hubungan antara pendapatan rumah tangga terhadap determinannya (faktor-faktor yang mempengaruhinya). 2) Selanjutnya kerangka dasar model Meng Xin dan Harry Wu tersebut di wadahi dalam kerangka model dasar dari metoda analisis FD (First Difference). 3) Selanjutnya terhadap model dasar dari metoda FD tersebut dilakukan perubahan dalam variabelvariabelnya determinan-nya dengan memasukkan variabel sewa lahan dan modal kapital.

Penelitian ini bertujuan untuk menganalisis pengaruh sewa lahan dan modal kapital terhadap pendapatan rumah tangga di Indonesia. Meskipun penelitian ini terfokus pada modal kapital dan sewa lahan, tetapi juga memasukan variabel lainnya yang ikut mempengaruhi pendapatan rumah tangga. Selanjutnya penelitian ini akan menggunaan metoda FD (First Difference) yang biasa digunakan untuk tujuan evaluasi terhadap kebijakan (Impact Evaluation) yang relatif jarang di pergunakan untuk kasus penelitian seperti yang akan dilakukan tersebut. Kemudian dalam penelitian ini menggunakan unit analisis rumah tangga untuk melihat kemampuannya dalam melengkapi pemahaman tentang pendapatan tidak hanya secara indidual tetapi juga antarrumah tangga. Adapun permasalahan yang akan dipelajari dalam penelitian ini adalah mencari jawaban dari beberapa pertanyaan: 1) Bagima- 
na pengaruh modal kapital dan sewa lahan terhadap pendapatan rumah tanggga di Indonesia?, 2) Bagaimana pengaruh faktor-faktor lainnya: pendidikan, pengalaman, jumlah tenaga kerja, pangsa (share) pekerja perempuan terhadap pekerja laki-laki, jumlah anggota keluarga dan modal sosial (arisan) terhadap pendapatan dan upah rumah tangga di Indonesia?.

Penelitian ini akan menggunakan panel data pada dua periode waktu yaitu tahun 2000 sebagai periode awal, dan tahun 2007 sebagai periode akhir. Periode tahun 2000 akan dianggap sebagai periode awal sebelum dikenakan kebijakan (pre-treatment), karena penelitian ini menyesuaikan atau peniruan dengan istilah yang dipergunakan dalam evaluasi kebijakan, walaupun sebenarnya kita tidak melakukan evalusi terhadap penerapan suatu kebijakan. Model dasar yang akan dipergunakan adalah sebagai berikut :

$Y_{i t}=\alpha+\beta t+\gamma T_{i t}+\varepsilon_{i t}$

Artinya bahwa perubahan yang terjadi pada periode akhir terhadap periode awal akan ditangkap oleh koefisien $(\gamma)$ yang ada didepan varibel $(T)$. Hal tersebut berdasarkan rujukan literatur mengenai metodologi evalusi kebijakan dengan menggunakan metoda FD. Terhadap model tersebut akan ditambahkan beberapa variabel yang mewakili masing masing determinan dari: 1) modal kapital dan sewa lahan, 2) Variabel lainnya: modal manusia, potensi karakteristik dan struktur rumah tangga dan potensi modal sosial.

Berdasarkan model ekonometrika dasar dalam metoda FD tersebut, selanjutnya model tersebut diubah variabel-nya sehingga sesuai dan menjadi model ekonometrika operasional untuk digunakan untuk mengukur dan menguji pengaruh determinan pendapatan rumah tangga terhadap pendapatan rumah tangga. Adapun model ekonometika dasar yang variabelnya sudah diubah tertsebut adalah:

$$
\begin{array}{r}
\ln H I_{i t}=\ln \text { Wage }_{i t}=\alpha+\beta \text { Time }+ \\
\gamma \text { ln Determinan } \\
\text { it }
\end{array}
$$

Keterangan:

HI = Wage = Pendapatan atau upah rumah tangga. Determinan $=$ Determinan pendapatan rumah tangga. Time $=$ Dummy waktu (Dummy_periode akhir). $\boldsymbol{\alpha}, \boldsymbol{\beta}, \boldsymbol{\gamma}=$ Koefisien dari konstanta, dummy waktu, dan determinan pendapatan rumah tangga. $\varepsilon=$ Error term dari determinan pendapatan rumah tangga. $\mathbf{i}=$ unit rumah tangga/kelurahan/desa. $\mathbf{t}=$ periode waktu.

Berdasarkan model dasar yang sudah diubah variabelnya tersebut, maka langkah berikutnya adalah melengkapi secara bertahap variabel yang sudah dipilih untuk mewakili masing-masing kelompok determinan. Langkah pertama adalah melengkapi model dasar dengan kelompok determinan yang akan menjadi fokus penelitian ini yaitu determinan modal manusia. Untuk selanjutnya dibuat model turunannya, yaitu melalui langkah secara bertahap memasukan variabel-variabel yang mewakili ketiga determinan sisanya. Model lengkap yang akan dipergunakan, adalah:

$$
\begin{aligned}
\text { ln } H I_{i t}= & \ln \text { Wage }_{i t}=\alpha+\beta \text { Time }_{2007}+ \\
& \gamma_{1} \text { Educ }_{\text {mean }}+\gamma_{3} \text { Exp }_{i t}+\gamma_{4} \text { exp }_{i t}^{2}+ \\
& \gamma_{5}{\text { Labor }+\gamma_{6} \text { LabFem }_{\text {avg }}+}_{i t}+ \\
& \gamma_{7} \text { Capital }_{i t}+\gamma_{8} \text { Land_rent }_{i t}+ \\
& \gamma_{9} \text { Fsize }_{+} \gamma_{10} \text { Arisan }_{i t}+\varepsilon_{i t}
\end{aligned}
$$

Keterangan:

$\mathbf{P R}=$ Pendapatan rumah tangga (total dalam Rupiah) $=$ HI (Household Income) atau Wage (upah). Time $_{2007}=$ Periode waktu (dummy 2007). Labour $=$ Tenaga kerja (jumlah pekerja dalam rumah tangga). LabFem_avg $=$ pangsa TK perempuan thd TK laki-laki di rumah tangga. educ $=$ Pendidikan (rata-rata tahun pendidikan dari pekerja di rumah tangga). exp= Pengalaman (rata-rata tahun pengalaman kerja dari pekerja di rumah tangga). fsize $=$ Jumlah anggota rumah tangga (orang). Capital= Nilai total stok modal pada suatu rumah tangga (Rupiah). Land_rent= Sewa lahan (ha). Arisan= Modal Sosial (jumlah kehadiran rumah tangga pada kegiatan arisan dalam setahun). $\alpha, \beta,=$ Koefisien dari konstanta, dan koefisien dari dummy waktu. $\gamma_{\mathbf{n}}=$ Koefisien dari varibel determinan pendapatan rumah tangga. $\varepsilon=$ Error term dari determinan pendapatan rumah tangga $\mathbf{i}=$ Unit rumah tangga. $\mathbf{t}=$ Time

Data dan sistematika analisis. Data yang akan dipergunakan adalah data panel yang bersumber dari IFLS (Indonesian Family Life 
Survey). Alasan penggunaan IFLS adalah sebagai berikut: a) Data yang dikumpulkan dalam publikasi IFLS adalah data panel (panel data), yaitu kelompok data yang sering disebut juga data longitudinal (longitudinal data). Berbeda dengan data antarwaktu (cross section) maupun data deret waktu (time series), data panel dikumpulkan berdasarkan unit yang sama (individu, keluarga, perusahaan, kota, negara, dan lainnya) antarwaktu (Woolridge, 2009), b) Seluruh komponen data yang diperlukan dalam penelitian ini semuanya tersedia dalam cakupan data IFLS. Keseluruhan data tersebut mencakup data-data indikator dari seluruh variabel dalam model yang dipergunakan pada penelitian ini. Berdasarkan kedua alasan tersebut di atas, maka diharapkan penggunaan data IFLS pada penelitian ini mampu memberikan informasi yang utuh dan teguh. Artinya mampu melakukan penelusuran mengenai perubahan pada unit rumah tangga yang sama antar waktu secara tajam. Selain alasan tersebut di atas, data IFLS sudah diakui secara internasional memiliki kualitasnya yang baik, terutama memiliki tingkat ke-tidak-sinambungan (attrition) data yang rendah, atau rendahnya tingkat kehilangan data pada individu yang sama antar waktu. Cakupan data IFLS meliputi data dari 13 provinsi, 321 data komunitas (kelurahan/desa) dan sekitar 22.000 data individual.

Adapun data IFLS yang akan dipergunakan dalam penelitian ini adalah IFLS-3 tahun 2000 dan IFLS-4 tahun 2007. Alasan penggunaan pada dua survei tersebut karena: a) Penggunaan dua titik waktu yaitu tahun 2000 dan tahun 2007 mencukupi kebutuhan data untuk analisis pengujian perubahan pada variabel yang diteliti pada sebuah rentang antar waktu. b) Kedua kelompok data tersebut adalah dua gelombang survei (wave) yang terakhir dilakukan, sehingga diharapkan didapatkan informasi terkini pada variabel-variabel yang akan diuji dalam penelitian tersebut. Pengolahan data akan menggunakan perangkat lunak (software) STATA, karena program Stata sangat memungkinkan dalam melakukan pengolahan data tersebut.

Pengolahan data dan sistematika pembahasan akan dilakukan secara bertahap. Tahap ke-1 adalah melakukan regresi parsial terhadap masing-masing variabel Capital, LandRent, terhadap variabel dependen-nya:

In_HI, In_HI_mean, In_Wage, In_Wage_mean. Pada tahapan ini akan diketahui signifikansi pengaruh dari masing-masing variabel secara parsial.

Pada Tahap ke-2 akan dilakukan regresi secara keseluruhan dengan menambahkan variabel-variabel lain yang ikut mempengaruhi terhadap pendapatan rumah tangga (Educ_mean, Exp_mean, Labor, LabFem_avg, Fsize, Arisan_num, dan Time). Pada tahapan ini akan terlihat bagaimana signifikansi variabel-variabel determinan tersebut secara bersama-sama (keseluruhan).

\section{Hasil dan Pembahasan}

Berdasarkan hasil regresi secara parsial dan hasil regresi keseluruhan (Tabel dalam Lampiran) dapat disimpulkan bahwa peningkatan sewa lahan pertanian (Land_rent) menyebabkan penurunan terhadap total pendapatan (HI) maupun rata-rata pendapatan (HI_mean) dan terhadap rata-rata upah (Wage_mean) maupun total upah (Wage) rumah tangga di Indonesia. Hasil penelitian ini sesuai dengan hasil penelitian yang sudah dilakukan oleh Aghion dkk (1999), Townsend dan Kaboski (2005), Glewwe dan Grosh (1998), dan Hall dkk (1999) bahwa peningkatan sewa lahan berpengaruh negatif dan signifikan terhadap peningkatan pendapatan (individu/rumah tangga).

Bahwa peningkatan sewa lahan pertanian berpengaruh signifikan terhadap penurunan upah dan pendapatan rumah tangga di Indonesia. Artinya peran sewa lahan terhadap perubahan upah dan pendapatan petani di Indonesia adalah kuat dan signifikan. Hal tersebut menunjukkan bahwa petani di Indonesia sudah sangat dominan sebagai petani penggarap dan bukan sebagai petani pemilik lahan, atau setidak-tidaknya sewa lahan pertanian adalah bagian yang penting dalam usaha sektor pertanian. Hal tersebut harusnya menjadi perhatian pemerintah dan para pengambil kebijakan khususnya di bidang pertanian, umumnya bagi para pengambil kebijakan yang berupaya meningkatkan pendapatan masya- 
rakat karena sektor pertanian adalah lapangan kerja utama masyarakat Indonesia.

Bahwa jumlah modal (Capital) menyebabkan penurunan tidak hanya terhadap total upah dan total pendapatan, tetapi juga terhadap rata-rata upah dan rata-rata pendapatan rumah tangga. Penjelasan dari hal ini ada beberapa kemungkinan: 1) Bahwa sektor usaha dominan dari masyarakat Indonesia adalah sektor pertanian dimana komponen modal kapital adalah relatif kecil (bila dibanding sektor non-pertanian). Sehingga peningkatan modal kapital hanya menyebabkan penurunan dalam total pendapatan. 2) Bahwa perputaran dana usaha (cash-flow) sektor pertanian terkendala waktu dan musim, sehingga petani banyak yang harus melakukan pinjaman modal dahulu ke lembaga keuangan resmi maupun tidak resmi sebelum bercocok tanam. Kondisi tersebut memungkinkan beban modal kapital menjadi tidak efisien bagi usaha sektor pertanian. 3) Komponen modal kapital yang dimasukan dalam penelitian ini adalah total keseluruhan modal kapital (uang) yang digunakan dalam usaha sektor pertanian dan non pertanian. Sehingga hasil regresi tersebut hanya terbatas menjelaskan hubungan komponen modal kapital uang saja terhadap pendapatan dan upah rumah tangga. Hasil penelitian ini bertentangan dengan hasil penelitian yang sudah dilakukan oleh Aghion dkk (1999), Townsend dan Kaboski (2005), Glewwe dan Grosh (1998) Hall dkk (1999) Meng Xin dan Wu Harry (1994) bahwa peningkatan modal kapital berpengaruh positif dan signifikan terhadap peningkatan pendapatan (individu/rumah tangga). Selanjutnya hasil penelitian ini juga bertentangan dengan hasil penelitian yang sudah dilakukan oleh Sai Ding $d k k$ (2009) bahwa peningkatan jumlah pekerja wanita berpengaruh positif dan signifikan terhadap peningkatan pendapatan (indivi$\mathrm{du}$ /rumah tangga).

Sedangkan peningkatan pada tingkat ratarata pendidikan pekerja (Educ_mean), rata-rata pengalaman pekerja (Exp_mean), dan modal sosial (Arisan) berpengaruh signifikan terhadap peningkatan total pendapatan (HI) maupun rata-rata pendapatan (HI_mean) dan terhadap rata-rata upah (Wage_mean) maupun total upah (Wage) rumah tangga. Sedangkan peningkatan pangsa pekerja wanita terhadap laki laki (LabFem_avg) menyebabkan penurunan tidak hanya terhadap total upah dan total pendapatan rumah tangga tetapi juga terhadap ratarata upah dan rata-rata pendapatan. Kemudian jumlah pekerja di rumah tangga (Labor) berpengaruh positif dan signifikan terhadap total upah dan total pendapatan, tapi berpengaruh negatif dan signifikan terhadap rata-rata upah dan rata-rata pendapatan rumah tangga di Indonesia. Sedangkan jumlah anggota rumah tangga (Fsize) berbanding terbalik dengan ratarata pendapatan dan rata-rata upah.

\section{Simpulan}

Berdasarkan hasil dalam pembahasan masalah di atas, serta kaitannya dengan pertanyaan dalam identifikasi masalah, maka dapat disimpulkan:

Bahwa peningkatan sewa lahan pertanian (Land_rent) menyebabkan penurunan terhadap total pendapatan (HI) maupun rata-rata pendapatan (HI_mean) dan terhadap rata-rata upah (Wage_mean) maupun total upah (Wage) rumah tangga di Indonesia. Hal tersebut menunjukan bahwa petani di Indonesia sudah sangat dominan sebagai petani penggarap dan bukan sebagai petani pemilik lahan, atau stidaktidaknya sewa lahan pertanian adalah bagian yang penting dalam usaha sektor pertanian.

Bahwa peningkatan jumlah modal (Capital) menyebabkan penurunan tidak hanya terhadap total upah dan total pendapatan, tetapi juga terhadap rata-rata upah dan rata-rata pendapatan rumah tangga.

Berdasarkan hasil regresi secara parsial dan regresi keseluruhan menunjukan bahwa peningkatan pada tingkat rata-rata pendidikan pekerja (Educ_mean), rata-rata pengalaman pekerja (Exp_mean), dan modal sosial (Arisan) berpengaruh signifikan terhadap peningkatan total pendapatan $(\mathrm{HI})$ maupun rata-rata pendapatan (HI_mean) dan terhadap rata-rata upah (Wage_mean) maupun total upah (Wage) rumah tangga.

Bahwa peningkatan pangsa pekerja wanita terhadap laki laki (LabFem_avg) menyebabkan penurunan tidak hanya terhadap total upah dan total pendapatan rumah tangga tetapi juga 
terhadap rata-rata upah dan rata-rata pendapatan. Kemudian jumlah pekerja di rumah tangga (Labor) berpengaruh positif dan signifikan terhadap total upah dan total pendapatan, tapi berpengaruh negatif dan signifikan terhadap rata-rata upah dan rata-rata pendapatan rumah tangga di Indonesia. Selanjutnya peningkatan jumlah anggota rumah tangga (Fsize) berpengaruh signifikan terhadap penurunan tidak hanya total upah dan total pendapatan tapi juga terhadap rata-rata upah dan rata-rata pendapatan rumah tangga di Indonesia.

\section{Daftar Pustaka}

Biro Pusat Statistik, 2 Januari 2012, "Profil Kemiskinan di Indonesia September 2011" Berita Resmi Statistik,No. 06/01/Th. XV.

Blau David M., Behrman Jere R. and Wolfe Barbara L., Aug., 1988, Schooling and Earnings Distributions with Endogenous Labour Force Participation, MaritalStatus and Family Size, Economica, New Series, Vol. 55, No. 219, pp. 297-316.

Deininger Klaus And John Okidi, (2002), Growth And Poverty Reduction in Uganda, 19922000: Panel Data Evidence,World Bank, Washington Dc And Economic Policy Research Council, Kampala.

Ding Sai, Xiao-Yuan Dong, And Shi Li, Women' $S$ Employment and Family Income Inequality During China' $S$ Economic Transition, Feminist Economics 15(3), July 2009, 163-190.

Fafchamps Marcel and Agnes R. Quisumbing, (Spring, 1999), Human Capital, Productivity, and Labor Allocation in Rural Pakistan, The Journal of Human Resources, Vol. 34, No. 2 pp. 369-406.

Glewwe Paul, Margaret E. Grosh, (Winter, 1998), Data Watch: The World Bank's Living Standards Measurement Study Household Surveys, The Journal of Economic Perspectives, Vol. 12, No. 1, pp. 187196.
Glewwe Paul, Michele Gragnolati, Hassan Zaman, (July 2002), Who Gained from Vietnam's Boom in the 1990s?, Economic Development and Cultural Change, Vol. 50, No. 4, pp. 773-792.

Hazell Peter, Shenggen Fan, S. K. Thorat, (Sep. 30 - Oct. 6, 2000), Impact of Public Expenditure on Poverty in Rural India, Economic and Political Weekly, Vol. 35, No. 40, pp. 3581-3588.

Howard White, Shampa Sinha and Ann Flanagan, 1999, A review of the state of impact evaluation, Independent Evaluation Group, World Bank,

Meng Xin and Wu Harry, (1994), Household Income Determination And Regional Income Differential in Rural Chin, Research School Of Pacific and Asian Studies, Australian National University MPRA Paper No. 1345, Jel Classification Codes: R2 And J4.

OECD, 2001, The Well-being of Nations: The Role of Human and Social Capital, OECD (Organisation for Economic Co-operation and Development), 18, Paris.

OECD, September 2012, Overview Economic Surveys of Indonesia, http://www.oecd. org/eco/surveys/Indonesia

Rahman Sayma, Rafiqul Bhuyan Rafiq, Mohammad A. Momen, Impact of Microcredit Programs on Higher Income Borrowers: Evidence from Bangladesh, International Business \& Economics Research Journal, February 2009 Volume 8, Number 2.

Ravalion Martin, 2008, Evaluating Ant- poverty Program, Handbook of development Economics, Volume 4, Elvesier B.V DOI: 10.1016/S1573-4471(07)04059-4.

Shahidur R. Khandker, Gayatri B. Koolwal, dan Hussain A. Samad, 2010, Handbook on Impact Evaluation Quantitative Methods and Practices, World Bank.

Singh Kehar, Madan Mohan Dey, Sources of family income and their effects on family income inequality: a study of fish farmers in 
Tripura India, Food Sec. (2010), Published online: 12 October 2010, ,Springer Science, Business Media B.V. \& International Society for Plant Pathology 2010.

Townsend Robert M. and Joseph P. Kaboski, (Mar., 2005), Policies and Impact: An Analysis of Village-Level Microfinance Institutions, Journal of the European Economic Association, Vol. 3, No. 1, pp. 1-50.
UNDP, 2012, Human Development Report (HDR) 2011, New Yok.

Woolridge M Jefrey, 2009, Introductory Econometrics: A Modern Approach, $4^{\text {th }}$ edition, South Western Cengage Learning, United States.

World Bank, 2013, Data Indicatators, http:// data.worldbank.org/indicator/SP.POP.D PND.

\section{LAMPIRAN}

Tabel 1. Spesifikasi Variabel dan Alasan Pemilihan

\begin{tabular}{|c|c|c|c|}
\hline No & Determinan & Spesifikasi Variabel & Alasan Pemilihan Variabel \\
\hline 1. & Modal Manusia & $\begin{array}{l}\text { Labor=Jumlah pekerja dalam } \\
\text { rumah tangga, usia 15-74 dan } \\
\text { bekerja lebih dari } 10 \text { hari dalam } \\
\text { setahun. } \\
\text { Educ=Rata-rata lama tahun } \\
\text { sekolah dari pekerja di rumah } \\
\text { tangga tersebut. } \\
\text { exp=Rata-rata usia per pekerja di } \\
\text { rumah tangga dikurangi tujuh } \\
\text { tahun (usia mulai sekolah dasar) } \\
\text { dikurangi rata-rata tahun sekolah } \\
\text { per pekerja tsb. } \\
\text { LabFem_avg=Jumlah total } \\
\text { pekerja wanita di rumah tangga } \\
\text { tersebut di bagi jumlah pekerja di } \\
\text { rumah tangga tersebut. }\end{array}$ & $\begin{array}{l}\text { Labor= Merupakan input produksi utama yang paling } \\
\text { umum dan paling penting } \\
\text { exp dan educ =Untuk menangkap unsur kualitas } \\
\text { sumber daya manusia, tingkat produktifitas termasuk } \\
\text { aspek kewirausahaan (entrepeneurshif). } \\
\text { LabFem_avg= Peran pekerja wanita sangat penting } \\
\text { dalam peningkatan kesejahteraan rumah tangga, } \\
\text { tetutama di negara-negara berkembang. } \\
\text { Sumber: } \\
\text { (Meng Xin dan Wu Harry, 1994), } \\
\text { (Ravallion dan Wodon, 2000). } \\
\text { (Fafchamps and Quisumbing, 1999),(Creamer, 1961), } \\
\text { (Sai Ding dkk, 2009). }\end{array}$ \\
\hline 2. & $\begin{array}{l}\text { Struktur } \\
\text { Keluarga }\end{array}$ & $\begin{array}{l}\text { Fsize }=\text { Jumlah anggota rumah } \\
\text { tangga tersebut }\end{array}$ & $\begin{array}{l}\text { fsize }=J u m p a h \text { anggota rumah tangga diyakini } \\
\text { berpengaruh kuat terhadap kesejahteraan rumah tangga. } \\
\text { Sumber : } \\
\text { (Todd dkk, 1996), (Greif, 2006), } \\
\text { (Creamer, 1961), } \\
\text { (Ravallion dan Wodon, 2000), } \\
\text { (Meng Xin dan Wu Harry, 1994). }\end{array}$ \\
\hline 3 & Modal Kapital & $\begin{array}{l}\text { Capital=Total stok modal yang } \\
\text { dimiliki oleh suatu rumah tangga. } \\
\text { Land_rent=Sewa lahan oleh } \\
\text { suatu rumah tangga }\end{array}$ & $\begin{array}{l}\text { Capital dan Land_rent= Merupakan input yang } \\
\text { penting dalam proses produksi. } \\
\text { Sumber: } \\
\text { (Sayma Rahman dkk, 2009), } \\
\text { (Meng Xin dan Wu Harry, 1994), } \\
\text { (Aghion dkk, 1999), (Townsend dan Kaboski, 2005), } \\
\text { (Glewwe dan Grosh, 1998), (Hall dkk, 1999). }\end{array}$ \\
\hline
\end{tabular}


4. Modal sosial

Infrastruktur, potensi wilayah dan Faktor Eksogen
Arisan=Jumlah kehadiran rumah tangga dalam kegiatan arisan dalam setahun
Arisan=Dipilih kegiatan arisan, karena diyakini sebagai media interaksi sosial antar warga yang paling intensif dan umum terutama di pedesaan. Ukuran arisan sangat representatif untuk mengukur kekuatan jaringan (networking) social dalam masyarakat. Sumber:

(Easterly dan Levine, 1997),

(Aron, 1987),(May, 2010), (Blinder, 1973), (Creamer, 1961),

(Okten dan Osili, 2004),(Olken, 2008).

Faktor Pendapatan/upah (level rumah tangga) memiliki masalah dalam variasi data (menjadi relatif homoden ketika di agregasi ke level Infrastruktur (level kelurahan/desa). Sedangkan variabel eksogen tidak bisa di intervensi.

Tabel 2. Spesifikasi Variabel dan Sumber Data

\begin{tabular}{|c|c|c|c|}
\hline VARIABEL & KETERANGAN & KOMPONEN & SUMBER \\
\hline HI & $\begin{array}{l}\text { Total pendapatan rumah } \\
\text { tangga (Household Income) } \\
\text { (Rupiah) }\end{array}$ & $\begin{array}{l}\text { Pendapatan upah (Wage) dari pekerja di } \\
\text { rumah tangga usia 10-75 tahun+ Pendapatan } \\
\text { bersih sektor pertanian (Agr)+Pendapatan } \\
\text { bersih sektor Non-pertanian (NonAgr) }\end{array}$ & $\begin{array}{l}\text { IFLS hh, Buku K= } \\
\text { ar15b, ar15a, ar09, } \\
\text { Buku 2= ut09, nt09 }\end{array}$ \\
\hline HI_mean & HI rata-rata (Rupiah) & $\begin{array}{l}\text { Pendapatan rata-rata di rumah tangga } \\
\text { tersebut }\end{array}$ & \\
\hline Wage & $\begin{array}{l}\text { Total Upah di Rumah tangga } \\
\text { (Wage) (Rupiah) }\end{array}$ & $\begin{array}{l}\text { Pendapatan upah dari pekerja di rumah } \\
\text { tangga usia 10-75 tahun }\end{array}$ & $\begin{array}{l}\text { IFLS hh, Buku K= } \\
\text { ar15b, ar15a, ar09. }\end{array}$ \\
\hline Wage_mean & Upah rata-rata (Rupiah) & Upah rata-rata dari pekerja di rumah tangga & \\
\hline Time & Dummmy waktu survey & $\begin{array}{l}D=1 \text { untuk tahun akhir (2007) dan } D=0 \\
\text { untuk waktu awal (2000) }\end{array}$ & \\
\hline Educ & $\begin{array}{l}\text { Total pendidikan (Education) } \\
\text { (tahun) }\end{array}$ & $\begin{array}{l}\text { Lama pendidikan yang ditempuh oleh pekerja } \\
\text { di rumah tangga }\end{array}$ & $\begin{array}{l}\text { IFLS hh, Buku K= } \\
\text { ar16, ar09, ar15a }\end{array}$ \\
\hline Educ_mean & Rata-rata pendidikan (Tahun) & $\begin{array}{l}\text { Rata-rata lama pendidikan dari pekerja di } \\
\text { rumah tangga }\end{array}$ & \\
\hline $\operatorname{Exp}$ & $\begin{array}{l}\text { Pengalaman kerja } \\
\text { (Experience) (Tahun) }\end{array}$ & $\begin{array}{l}\text { Usia pekerja (AgeLab)-7 tahun sebelum } \\
\text { sekolah-lama pendidikan (Educ) }\end{array}$ & $\begin{array}{l}\text { IFLS hh, Buku } \\
\text { K=ar16, ar09, ar15a }\end{array}$ \\
\hline Exp_mean & $\begin{array}{l}\text { Rata-rata pengalaman kerja } \\
\text { (Tahun) }\end{array}$ & $\begin{array}{l}\text { Rata-rata pengalaman kerja dari pekerja usia } \\
\text { 10-75 tahun di rumah tangga }\end{array}$ & \\
\hline AgeLab & $\begin{array}{l}\text { Usia pekerja (Age of labor) } \\
\text { (Tahun) }\end{array}$ & $\begin{array}{l}\text { Usia pekerja di rumah tangga (rentang 10-75 } \\
\text { tahun) }\end{array}$ & $\begin{array}{l}\text { IFLS hh, Buku K= } \\
\text { ar09, ar15a }\end{array}$ \\
\hline Labor & $\begin{array}{l}\text { Jumlah pekerja (Labor) } \\
\text { (orang) }\end{array}$ & $\begin{array}{l}\text { Jumlah pekerja yang bekerja usia 10-75 tahun } \\
\text { di rumah tangga }\end{array}$ & $\begin{array}{l}\text { IFLS hh, Buku K= } \\
\text { ar15a, ar09 }\end{array}$ \\
\hline LabFem_avg & $\begin{array}{l}\text { Pangsa (share) pekerja } \\
\text { perempuan (Female labor) }\end{array}$ & $\begin{array}{l}\text { Jumlah pekerja perempuan yang bekerja di } \\
\text { bagi jumlah total pekerja usia 10-75 tahun di } \\
\text { rumah tangga }\end{array}$ & $\begin{array}{l}\text { IFLS hh, Buku K= } \\
\text { ar15a, ar09, ar01a }\end{array}$ \\
\hline Capital & Total modal kapital (Rupiah) & $\begin{array}{l}\text { Pengeluaran total untuk usaha sektor } \\
\text { pertanian+Nilai lahan } \\
\text { pertanian+pengeluaran total untuk usaha } \\
\text { sektor Non-pertanian }\end{array}$ & $\begin{array}{l}\text { IFLS hh, Buku 2= } \\
\text { nt08, ut08, ut11 }\end{array}$ \\
\hline LandRent & $\begin{array}{l}\text { Luas lahan yang di sewa } \\
\text { (Rental of land) (ha) }\end{array}$ & $\begin{array}{l}\text { Total luas lahan yang disewa untuk usaha } \\
\text { rumah tangga }\end{array}$ & $\begin{array}{l}\text { IFLS hh, Buku2= } \\
\text { ut01b }\end{array}$ \\
\hline Fsize & $\begin{array}{l}\text { Jumlah anggota tumah tangga } \\
\text { (Family size) (Orang) }\end{array}$ & Total jumlah anggota rumah tangga & $\begin{array}{l}\text { IFLS hh, Buku K= } \\
\text { ar01a }\end{array}$ \\
\hline Arisan_num & Total kehadiran dalam arisan & $\begin{array}{l}\text { Jumlah kehadiran dari seluruh anggota } \\
\text { rumah tangga dalam kegiatan arisan dalam } \\
\text { satu tahun }\end{array}$ & $\begin{array}{l}\text { IFLS hh, Buku 3B= } \\
\text { pm01 }\end{array}$ \\
\hline Arisan_01 & $\begin{array}{l}\text { Total keaggotaan dalam } \\
\text { arisan }\end{array}$ & $\begin{array}{l}\text { Jumlah anggota rumah tangga yang menjadi } \\
\text { anggota dalam kegiatan arisan }\end{array}$ & $\begin{array}{l}\text { IFLS hh, Buku } 3 B= \\
\text { pm01c }\end{array}$ \\
\hline
\end{tabular}


Tabel 4. Ringkasan Statistik

\begin{tabular}{|c|c|c|c|c|c|}
\hline Variable | & Obs & Mean & Std. Dev. & Min & Max \\
\hline HI | & 21472 & $1.48 e+07$ & $3.53 e+07$ & 1400 & $2.01 e+09$ \\
\hline HI_mean | & 21472 & 7842672 & $1.75 e+07$ & 1400 & $1.00 e+09$ \\
\hline$\overline{\ln } \_\mathrm{HI}$ & 21472 & 15.75623 & 1.272558 & 7.244227 & 21.41891 \\
\hline ln_HI_mean | & 21472 & 15.19515 & 1.209762 & 7.244227 & 20.72327 \\
\hline Wage | & 21472 & $1.47 e+07$ & $3.53 e+07$ & 1400 & $2.01 e+09$ \\
\hline---- & & --- & & & \\
\hline Wage_mean | & 21472 & 7814050 & $1.75 e+07$ & 1400 & $1.00 e+09$ \\
\hline In_Wage | & 21472 & 15.74578 & 1.27848 & 7.244227 & 21.41891 \\
\hline In_HI_mean | & 21472 & 15.19515 & 1.209762 & 7.244227 & 20.72327 \\
\hline Time | & 21472 & 1.047923 & 1.259008 & 0 & 11 \\
\hline Educ mean | & 21472 & 8.727453 & 3.860232 & 0 & 24 \\
\hline--+ & & --------- & -- & & -1 \\
\hline Exp mean | & 21472 & 21.56271 & 12.17623 & -5 & 68 \\
\hline Exp_mean2 | & 21472 & 613.204 & 698.8567 & 0 & 4624 \\
\hline Labor | & 21472 & 2.052766 & 1.293521 & 1 & 18 \\
\hline Labor fem | & 21472 & 1.028689 & .9446103 & 0 & 14 \\
\hline LabFem_avg | & 21472 & .504969 & .3957599 & 0 & 1 \\
\hline Capital & 21,25 & $2360+07$ & $10+00$ & 0 & $3510 \quad 5$ \\
\hline In Cap & 21472 & 3.162095 & 6.027544 & 0 & 26.58368 \\
\hline Land rent & 21472 & 7.458807 & 105.4287 & 0 & 3600 \\
\hline$\overline{\text { Fsize }}$ & 21472 & 1.586904 & 1.175009 & 0 & 18 \\
\hline Arisan | & 21472 & 1.245902 & 3.632747 & 0 & 65 \\
\hline
\end{tabular}

Tabel 5. Pengaruh Pendidikan, Pengalaman, Tenaga Kerja dan Pangsa Pekerja Wanita, Modal dan Sewa lahan, Jumlah Anggota Rumah tangga dan Arisan terhadap Pendapatan dan Upah Rumah Rangga

\begin{tabular}{|c|c|c|c|c|}
\hline & $\begin{array}{r}(1) \\
\text { ln_HI }\end{array}$ & $\begin{array}{r}(2) \\
\text { In_Wage }\end{array}$ & In_HI_mean & $\begin{array}{r}(4) \\
\text { In_Wage_mn }\end{array}$ \\
\hline Time & $\begin{array}{l}0.304^{* * *} \\
(0.00712)\end{array}$ & $\begin{array}{l}0.320 * \star \star \\
(0.00717)\end{array}$ & $\begin{array}{l}0.278 * * * \\
(0.00720)\end{array}$ & $\begin{array}{c}0.295^{* * *} \\
(0.00728)\end{array}$ \\
\hline Educ_mean & $\begin{array}{c}0.157^{\star * *} \\
(0.00215)^{2}\end{array}$ & $\begin{array}{c}0.158^{* \star *} \\
(0.00215)\end{array}$ & $\begin{array}{c}0.157^{* * *} \\
(0.00215)^{(1)}\end{array}$ & $\begin{array}{c}0.158 * * * \\
(0.00216)\end{array}$ \\
\hline Exp_mean & $\begin{array}{l}0.0460 * \star \star \\
(0.00208)\end{array}$ & $\begin{array}{l}0.0455^{\star \star \star} \\
(0.00209)\end{array}$ & $\begin{array}{l}0.0393^{* \star *} \\
(0.00208)\end{array}$ & $\begin{array}{l}0.0388^{\star \star \star *} \\
(0.00209)\end{array}$ \\
\hline Exp_mean2 & $\begin{array}{l}-0.000738 * * * \\
(0.0000366)\end{array}$ & $\begin{array}{l}-0.000733^{* * *} \\
(0.0000368)\end{array}$ & $\begin{array}{l}-0.000614 * \star * \\
(0.0000366)\end{array}$ & $\begin{array}{l}-0.000609 * * * \\
(0.0000369)\end{array}$ \\
\hline Labor & $\begin{array}{c}0.229 * * * \\
(0.00991)\end{array}$ & $\begin{array}{c}0.219 * * * \\
(0.00995)\end{array}$ & $\begin{array}{l}-0.145^{* \star *} \\
(0.0103)\end{array}$ & $\begin{array}{l}-0.155^{\star \star *} \\
(0.0104)\end{array}$ \\
\hline LabFem_avg & $\begin{array}{l}-0.0377^{\star} \\
(0.0171)\end{array}$ & $\begin{array}{l}-0.0369 * \\
(0.0172)\end{array}$ & $\begin{array}{l}-0.0418^{*} \\
(0.0171)\end{array}$ & $\begin{array}{l}-0.0409 * \\
(0.0172)\end{array}$ \\
\hline In_Cap & $\begin{array}{l}-0.0111^{* * *} \\
(0.00136)\end{array}$ & $\begin{array}{l}-0.00843 * * * \\
(0.00136)\end{array}$ & $\begin{array}{l}-0.0159 * * * \\
(0.00138)\end{array}$ & $\begin{array}{l}-0.0133 * * * \\
(0.00138)\end{array}$ \\
\hline Land_rent & $\begin{array}{l}-0.000187 * * \\
(0.0000684)\end{array}$ & $\begin{array}{l}-0.000214 * * \\
(0.0000682)\end{array}$ & $\begin{array}{l}-0.000215^{\star *} \\
(0.0000699)\end{array}$ & $\begin{array}{l}-0.000242 * \star * \\
(0.0000704)\end{array}$ \\
\hline Fsize & $\begin{array}{l}-0.0368 * * * \\
(0.00950)\end{array}$ & $\begin{array}{l}-0.0396 * \star \star \\
(0.00953)\end{array}$ & $\begin{array}{l}-0.0522 * * * \\
(0.00957)\end{array}$ & $\begin{array}{l}-0.0550 * * * \\
(0.00962)\end{array}$ \\
\hline Arisan & $\begin{array}{l}0.00925 * * * \\
(0.00214)\end{array}$ & $\begin{array}{l}0.0106 * * * \\
(0.00214)\end{array}$ & $\begin{array}{l}0.0134 * * * \\
(0.00230)^{*}\end{array}$ & $\begin{array}{l}0.0148^{* * *} \\
(0.00231)\end{array}$ \\
\hline _cons & $\begin{array}{l}13.16^{* \star \star} \\
(0.0404)\end{array}$ & $\begin{array}{l}13.15^{\star \star \star} \\
(0.0404)^{-}\end{array}$ & $\begin{array}{l}13.50 * \star \star \\
(0.0405)\end{array}$ & $\begin{array}{l}13.48 * \star * \\
(0.0405)\end{array}$ \\
\hline $\begin{array}{l}\mathrm{N} \\
\mathrm{R}-\mathrm{sq} \\
\text { adj. R-sq } \\
\text { rmse }\end{array}$ & $\begin{array}{l}21472 \\
0.449 \\
0.449 \\
0.945\end{array}$ & $\begin{array}{l}21472 \\
0.452 \\
0.452 \\
0.946\end{array}$ & $\begin{array}{l}21472 \\
0.392 \\
0.392 \\
0.944\end{array}$ & $\begin{array}{l}21472 \\
0.397 \\
0.397 \\
0.946\end{array}$ \\
\hline
\end{tabular}

Standard errors in parentheses

$\star \mathrm{p}<0.05, * * \mathrm{p}<0.01, * * * \mathrm{p}<0.001$ 